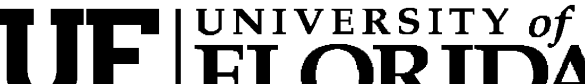 FLORIDA \\ IFAS Extension
}

\section{UF/IFAS Standardized Fertilization Recommendations for Agronomic Crops 1}

\author{
R. Mylavarapu, D. Wright, G. Kidder, C.G. Chambliss²
}

\section{Introduction}

This publication presents in abbreviated form the fertilization recommendations for agronomic crops based on soil tests performed by the UF/IFAS Extension Soil Testing Laboratory (ESTL). It contains the basic information from which ESTL soil-test reports and fertilization recommendations are generated.

\section{General Background}

Soil testing is a tool in crop fertilization management. Its successful use requires that: (1) you send to the lab soil samples that best represent your field or management unit; (2) the laboratory uses legitimate methods for predicting fertility; and (3) the fertilizer recommendations are based on measured crop responses.

The ESTL extracts phosphorus $(\mathrm{P})$, potassium $(\mathrm{K})$, magnesium $(\mathrm{Mg})$, and calcium $(\mathrm{Ca})$ with the Mehlich-1 extractant and bases fertilization recommendations for those nutrients on the test results. Current interpretation of test results are presented in Table 1 . Nitrogen $(\mathrm{N})$ fertilization is not based on soil tests but rather is based on crop needs as documented in research literature.

Liming recommendations are based on the Adams-Evans lime requirement test, a calibration equation developed for Florida soils, and on the target $\mathrm{pH}$ for the crop for which the recommendation is being made.

Soil test reports from the ESTL are computer-generated from lab data and crop codes. If a cropping situation is not in the list of crop codes, routine soil tests may not be appropriate. In such instances, the local county agent should be consulted before soil samples are sent for testing. Reports contain the results of the tests (soil $\mathrm{pH}$, ppm extractable $\mathrm{P}, \mathrm{K}, \mathrm{Mg}$, and $\mathrm{Ca}$ ), a rating of the $\mathrm{P}, \mathrm{K}$, and $\mathrm{Mg}$ (very high to very low), and the fertilization recommendation for the specified crop. The recommendation is composed of two parts: (1) the

1. This document is SL129, a fact sheet of the Soil and Water Science Department, Florida Cooperative Extension Service, Institute of Food and Agricultural Sciences, University of Florida. First printed February 1990 as "Notes in Soil Science \#35", revised as SL129, June 1997. Latest revision June 2007. Please visit the EDIS Website at http://edis.ifas.ufl.edu.

2. R. Mylavarapu, associate professor, Nutrient Management Specialist and Director of UF/IFAS Extension Soil Testing Laboratory, Soil and Water Science Department; D. Wright, professor, Agronomy Department, G. Kidder, professor emeritus, Soil and Water Science Department, C.G. Chambliss (deceased), associate professor, Agronomy Department, Florida Cooperative Extension Service, Institute of Food and Agricultural Sciences, University of Florida, Gainesville, FL 32611-0290.

The Institute of Food and Agricultural Sciences (IFAS) is an Equal Opportunity Institution authorized to provide research, educational information and other services only to individuals and institutions that function with non-discrimination with respect to race, creed, color, religion, age, disability, sex, sexual orientation, marital status, national origin, political opinions or affiliations. U.S. Department of Agriculture, Cooperative Extension Service, University of Florida, IFAS, Florida A. \& M. University Cooperative Extension Program, and Boards of County Commissioners Cooperating. Larry Arrington, Dean 
Table 1. Current Mehlich-1soil-test interpretations used for agronomic crops.

\begin{tabular}{|c|c|c|c|c|c|}
\hline Element & Very low & Low & Med & High & Very high \\
\hline & \multicolumn{5}{|c|}{------- parts per million soil --------- } \\
\hline $\mathrm{P}$ & $<10$ & $10-15$ & $16-30$ & $31-60$ & $>60$ \\
\hline $\mathrm{K}$ & $<20$ & $20-35$ & $36-60$ & $61-125$ & $>125$ \\
\hline $\mathrm{Mg}$ & & $<15$ & $15-30$ & $>30$ & \\
\hline
\end{tabular}

rates of $\mathrm{N}, \mathrm{P}_{2} \mathrm{O}_{5}$, and $\mathrm{K}_{2} \mathrm{O}$ fertilizer to apply; and (2) footnotes which give important information about fertilization management such as application timing, special crop requirements, etc.

Table 2 of this document contains crop codes, crop descriptions, target $\mathrm{pH}, \mathrm{N}$ recommendation, $\mathrm{P}_{2} \mathrm{O}_{5}$ and $\mathrm{K}_{2} \mathrm{O}$ recommendations for each of the five soil-test rating levels, the footnotes which will be printed for each of the crop codes, and the references upon which the recommendations are based. The text of the footnotes referred to in Table 2 is given below.

\section{Text of Footnotes}

102. Apply all of the $\mathrm{P}_{2} \mathrm{O}_{5}, 30 \%$ of the $\mathrm{K}_{2} \mathrm{O}$, and $30 \mathrm{lb}$ N/A in a preplant or at-planting application. Four weeks after planting, sidedress the remaining $70 \%$ of the $\mathrm{K}_{2} 0$. Apply the remaining $120 \mathrm{lb}$ N/A in two or more sidedressings, one of which should be at 4 weeks after planting.

104. Apply all of the $\mathrm{P}_{2} \mathrm{O}_{5}, 30 \%$ of the $\mathrm{K}_{2} \mathrm{O}$, and $30 \mathrm{lb}$ N/A in a preplant or at-planting application. Four weeks after planting, sidedress the remaining $70 \%$ of the $\mathrm{K}_{2} \mathrm{O}$. Apply the remaining $180 \mathrm{lb}$ N/A in three or more sidedressings, one of which should be at 4 weeks.

106. Apply all of the $\mathrm{P}_{2} \mathrm{O}_{5}$ and $30 \%$ of the $\mathrm{K}_{2} \mathrm{O}$ and $\mathrm{N}$ in a preplant or at-planting application. Topdress or sidedress the remaining $70 \%$ of the $\mathrm{K}_{2} \mathrm{O}$ and $\mathrm{N}$. For small grains grown for grain, silage, or hay, topdress during late January or early February. For grain sorghum or forage sorghum, sidedress before plants are too tall to cultivate or approximately 4 weeks after planting.

107. Apply all of the $\mathrm{P}_{2} \mathrm{O}_{5}$ and $30 \%$ of the $\mathrm{K}_{2} \mathrm{O}$ and $\mathrm{N}$ in a preplant or at-planting application. Apply the remaining $70 \%$ of the $\mathrm{K}_{2} \mathrm{O}$ and $\mathrm{N}$ in one sidedressing.
108. Application of 20 to $30 \mathrm{lb}$ N/A may give vegetative response but is unlikely to increase harvested yield.

109. If peanuts are grown for seed or if they are virginia type, regardless of soil test, apply gypsum in a band over the potential pegging zone at early flower. Apply $400 \mathrm{lb}$ gypsum/A for runner types and $800 \mathrm{lb}$ gypsum/A for virginia types. Double these rates if broadcasting granular or phosphogypsum (bulk wet). For peanuts not grown for seed, apply gypsum as recommended above only if the calcium soil-test level is below $250 \mathrm{ppm} \mathrm{Ca}$.

110. Apply $50 \%$ of the fertilizer at or before transplanting and the other half within 3 weeks of transplanting.

111. Apply $30 \mathrm{lb}$ N/A, $50 \%$ of the $\mathrm{K}_{2} \mathrm{O}$, and all of the $\mathrm{P}_{2} \mathrm{O}_{5}$ fertilizer in a preplant or at-planting application. Apply $50 \mathrm{lb}$ N/A and the remaining $\mathrm{K}_{2} \mathrm{O}$ after the first grazing period. Apply an additional $50 \mathrm{lb}$ N/A after each subsequent grazing period.

112. When planting on a prepared seed bed, apply $30 \mathrm{lb} \mathrm{N} / \mathrm{A}, 50 \%$ of the $\mathrm{K}_{2} \mathrm{O}$, and all of the $\mathrm{P}_{2} \mathrm{O}_{5}$ fertilizer in a preplant or at-planting application. Apply $50 \mathrm{lb} \mathrm{N} / \mathrm{A}$ and the remaining $\mathrm{K}_{2} \mathrm{O}$ after the first grazing period. Apply an additional $50 \mathrm{lb}$ N/A after each subsequent grazing period.

When overseeding established perennial grasses with cool season annual grasses, apply $50 \mathrm{lb}$ N/A plus all of the $\mathrm{P}_{2} \mathrm{O}_{5}$ and $\mathrm{K}_{2} \mathrm{O}$ after emergence. Apply an additional $50 \mathrm{lb}$ N/A after each subsequent grazing period. 
115. Apply all of the $\mathrm{P}_{2} \mathrm{O}_{5}$ and $\mathrm{K}_{2} \mathrm{O}$ fertilizer in late fall. If legumes are planted in combination with oats, rye, wheat, and/or ryegrass, apply 30 lb N/A in a preplant or at-planting application plus one additional $50 \mathrm{lb}$ N/A application after the grass is well established.

118. Apply $0.75 \mathrm{lb}$ boron/A in the fertilizer or $0.5 \mathrm{lb}$ boron/A as a foliar spray with the first fungicide application.

120. Fertilizer should contain 15 to $20 \mathrm{lb}$ sulfur/A. Apply as a sulfate (e.g., gypsum, ammonium sulfate, magnesium sulfate, potassium sulfate, potassium magnesium sulfate), since elemental sulfur will react too slowly to supply the sulfur needs of the current crop.

121. Apply all of the $\mathrm{P}_{2} \mathrm{O}_{5}$ and $\mathrm{K}_{2} \mathrm{O}$ in spring or early summer when seedlings or regrowth are 3 to 4 inches tall. Species included are aeschynomene, alyceclover, desmodiums, hairy indigo, perennial peanut, and other tropical legumes.

122. Species included are all true clovers (white, red, arrowleaf, crimson, subterranean), vetches, lupines, and sweet clover.

123. Apply all of the $\mathrm{P}_{2} \mathrm{O}_{5}$ and $50 \%$ of the $\mathrm{K}_{2} \mathrm{O}$ fertilizer in late fall. Apply the remaining $\mathrm{K}_{2} \mathrm{O}$ in early spring. If the alfalfa is mechanically harvested rather than grazed, apply an additional $30 \mathrm{lb} \mathrm{P}_{2} \mathrm{O}_{5} / \mathrm{A}$ and $60 \mathrm{lb} \mathrm{K} \mathrm{O}_{2} \mathrm{O} / \mathrm{A}$ after each harvest. An additional application of $100 \mathrm{lb} \mathrm{K}_{2} \mathrm{O} / \mathrm{A}$ in June or July may increase summer survival of alfalfa. Apply $3 \mathrm{lb}$ boron/A per year to alfalfa in three $1 \mathrm{lb} / \mathrm{A}$ applications. Copper and zinc fertilizer may be needed if soil $\mathrm{pH}$ is above 6.5.The lime requirement shown is adequate for established alfalfa. However if the alfalfa has not yet been planted, apply and incorporate one ton of lime/A if the soil pH is below 6.6. Lime is especially important for establishment of alfalfa. It is not practical to incorporate lime once the alfalfa is planted.

124. UF/IFAS fertilization and liming recommendations are advisory in nature and emphasize efficient fertilizer use and environmentally sound nutrient management without losses of yield or crop quality. It is generally assumed the nutrients will be supplied from purchased, commercial fertilizer and the expected crop yields and quality will be typical of economically viable production. Growers should consider IFAS recommendations in the context of their entire management strategy, such as return on investment in fertilizer and the benefits of applying manure or biosolids (sewage sludge) to their land.

There is insufficient research available to support the use of UF/IFAS soil test results for environmental nutrient management purposes. Such use is discouraged until correlation is proven.

125. Grass species included are bermuda, star, digit, and rhodesgrass.

126. FERTILIZATION MANAGEMENT NOTES FOR BERMUDAGRASS, STARGRASS, DIGITGRASS, AND RHODESGRASS

\section{Establishment of New Plantings}

For establishment of new plantings, apply $100 \mathrm{lb}$ N/A and split as follows: apply $30 \mathrm{lb}$ N/A, all of the $\mathrm{P}_{2} \mathrm{O}_{5}$, and $50 \%$ of the $\mathrm{K}_{2} \mathrm{O}$ as soon as plants have emerged. Apply the remaining $\mathrm{K}_{2} \mathrm{O}$ and 70 lb N/A 30 to 50 days later.

\section{Maintenance Fertilization of Established Pastures}

For grazed, established stands, apply $80 \mathrm{lb}$ N/A, all of the $\mathrm{P}_{2} \mathrm{O}_{5}$, and $50 \%$ of the $\mathrm{K}_{2} \mathrm{O}$ in early spring. Apply $80 \mathrm{lb} \mathrm{N}$ and the remaining $\mathrm{K}_{2} \mathrm{O}$ at mid-season.

Under intensive management in central and south Florida, up to $200 \mathrm{lb}$ N/A may be economically viable for stargrass and bermudagrass. In that situation, apply $80 \mathrm{lb}$ N/A, all of the $\mathrm{P}_{2} \mathrm{O}_{5}$ and $50 \%$ of the $\mathrm{K}_{2} \mathrm{O}$ in early spring, follow with $50 \mathrm{lb}$ N/A in mid-season, and 
$70 \mathrm{lb} \mathrm{N} / \mathrm{A}$ and the remaining $\mathrm{K}_{2} \mathrm{O}$ in mid- to late September.

\section{Making Hay, Silage, or Green Chop}

Apply $80 \mathrm{lb}$ N/A and all of the recommended $\mathrm{P}_{2} \mathrm{O}_{5}$ and $\mathrm{K}_{2} \mathrm{O}$ in early spring. Apply an additional $80 \mathrm{lb} \mathrm{N}$ and $40 \mathrm{lb} \mathrm{K}_{2} \mathrm{O} / \mathrm{A}$ after each cutting, except the last in the fall. Include $20 \mathrm{lb}$ of $\mathrm{P}_{2} \mathrm{O}_{5}$ in the supplemental fertilizer if the soil tested low or medium in $\mathrm{P}$.

\section{Special Note if Applying Manure or Biosolids}

A different set of economic factors are usually considered when waste materials rather than purchased fertilizer are supplying the nutrients. Additionally, it is often impractical to follow the application timings discussed above when using waste materials from other operations.

127. Apply all of the $\mathrm{P}_{2} \mathrm{O}_{5}, 50 \%$ of the $\mathrm{K}_{2} \mathrm{O}$, and $40 \mathrm{lb}$ N/A at planting. Topdress the remaining $\mathrm{N}$ and $\mathrm{K}_{2} \mathrm{O}$ in late January. On land which lacks clayey soil within the top 6 to 8 inches of the surface, apply 5 to $10 \mathrm{lb}$ sulfate-sulfur/A at planting and $10 \mathrm{lb}$ sulfate-sulfur/A in the topdressing. Wettable or other elemental forms of sulfur will react too slowly to supply the sulfur needs of the current crop. On flatwoods soils with $\mathrm{pH}$ above 6.1, apply $10 \mathrm{lb}$ manganese/A. On better-drained sands with $\mathrm{pH}$ above 6.5 , apply 6 to $10 \mathrm{lb}$ manganese/A.

128. The recommended rates of fertilizer are sufficient to produce soybean yields in the 60 $\mathrm{bu} / \mathrm{A}$ range. If yields from this field have never exceeded $40 \mathrm{bu} / \mathrm{A}$ under current management, reduce $\mathrm{P}_{2} \mathrm{O}_{5}$ and $\mathrm{K}_{2} \mathrm{O}$ recommendations by 20 $\mathrm{lb} / \mathrm{A}$. If yields from this field have never exceeded $25 \mathrm{bu} / \mathrm{A}$, reduce $\mathrm{P}_{2} \mathrm{O}_{5}$ and $\mathrm{K}_{2} \mathrm{O}$ recommendations by $40 \mathrm{lb} / \mathrm{A}$. Often this adjustment will mean that you will achieve your yield potential without any $\mathrm{P}$ or $\mathrm{K}$ fertilizer additions.

129. These recommendations are made assuming adequate soil moisture will be available either from rainfall or irrigation. In south Florida, lack of adequate rainfall during the cool season frequently causes stand failure or limits growth. Under nonirrigated conditions in south Florida, the probability of inadequate moisture is high, and the likelihood that the crop will benefit from applied fertilizer is low, especially on the drier soils.

130. For grazing or hay production of perennial peanuts, apply all of the $\mathrm{P}_{2} \mathrm{O}_{5}$ and $\mathrm{K}_{2} \mathrm{O}$ in early spring. For hay production, make an annual application of 20 to $30 \mathrm{lb}$ sulfur/A. Apply as a sulfate (e.g., gypsum, ammonium sulfate, magnesium sulfate, potassium sulfate, potassium magnesium sulfate). After each hay harvest, apply an additional 15 pounds of $\mathrm{P}_{2} \mathrm{O}_{5}$ and 40 pounds of $\mathrm{K}_{2} \mathrm{O}$ per ton of hay removed, unless the soil tested high or very high .

\section{FERTILIZATION MANAGEMENT NOTES FOR BAHIAGRASS}

Bahiagrass is probably the most widely-used improved forage grass in Florida. It responds well to grazing management and inputs such as fertilization. However, it also can persist and give satisfactory yields under low inputs. Because of the wide range of possible use and management levels, recommendations for Bahiagrass fertilization differ with the level of managment and the economic inputs.

Management decisions concerning liming and fertilization of Bahiagrass pastures are very sensitive to cattle productivity and prices.

\section{Liming}

In order to obtain maximum fertilization efficiency, soil $\mathrm{pH}$ should be maintained at 5.5. If soil $\mathrm{pH}$ is tested below 5.5, a lime requirement test will be conducted and a recommendation for lime application will be made. For lime requirement to be calculated and recommended, the tested soil $\mathrm{pH}$ should be at least $0.2 \mathrm{pH}$ units lower than the target $\mathrm{pH}$ of 5.5.

Lime should be applied at least 3 to 6 months prior to fertilization to provide adequate time for the lime reaction to occur and the soil $\mathrm{pH}$ to adjust to the desired level. Soils should be tested for $\mathrm{pH}$ every 2-3 years. 


\section{Phosphorus Fertilization}

Producers are encouraged strongly to submit both a soil and a tissue sample together when submitting samples to the ESTL when considering phosphorus fertilization. As per the preliminary research findings, soil tests alone were not found to be adequate to determine Bahiagrass phosphorus needs. A complementary tissue test has therefore been added to the testing procedures along with the soil test to determine the phosphorus fertilization needs. Both the consolidated soil and the tissue samples should be collected simultaneously from each field of up to 40 acres.

The testing procedures and the recommendations for phosphorus for Bahiagrass may be adjusted as and when field research data become available.

If the soil tests Very Low or Low in P, a tissue $\mathrm{P}$ analysis is conducted. Phosphorus application is not required if tissue $\mathrm{P}$ concentrations are at or above $0.15 \%$, even if soil tested very low or low in P. For medium and high soil $\mathrm{P}$ concentrations, neither $\mathrm{P}$ application nor tissue analysis is recommended since no added benefit from $\mathrm{P}$ fertilization on bahiagrass yields has been demonstrated. This is summarized in Table 3.

Table 3. Interpretation for Bahiagrass Soil and Tissue Test

\begin{tabular}{|l|cc|}
\hline \hline Soil Test & Tissue Test & Recommendations \\
\hline P Med / High & $\begin{array}{c}\text { No Tissue } \\
\text { Test }\end{array}$ & 0 \\
P Low / V Low & $\mathrm{P}>0.15 \%$ & 0 \\
$\mathrm{P}$ Low / V Low & $\mathrm{P}<0.15 \%$ & 25 lbs/acre $\mathrm{P}_{2} \mathrm{O}_{5}$ \\
\hline \hline
\end{tabular}

\section{Establishment of New Plantings}

For new plantings, apply $80 \mathrm{lb}$ N/A split as follows: apply $30 \mathrm{lb} \mathrm{N} / \mathrm{A}$, all of the $\mathrm{P}_{2} \mathrm{O}_{5}$, and $50 \%$ of the $\mathrm{K}_{2} \mathrm{O}$ as soon as plants have emerged. Apply the remaining $\mathrm{K}_{2} \mathrm{O}$ and $50 \mathrm{lb}$ N/A 30 to 50 days later. If manure or biosolids are used as the main source of nutrients, apply the entire annual application once the plants are large enough to withstand physical damage from the application.

\section{Maintenance Fertilization of Established Bahiagrass Pasture}

Four fertilization options are presented below for bahiagrass pastures. Choose the option which most closely fits your fertilizer budget, management objectives, and land capability.

If you will be only grazing your bahiagrass, you should carefully consider the potential for economical return on your investment in fertilizer before using the Medium-Nitrogen or High-Nitrogen options described below. The added forage produced for the grazing animals may not be worth the added cost.

\section{Low-Nitrogen Option (for Grazed Pastures}

Only). Do not use this option if you cut hay since nutrient removal by hay is much greater than by grazing animals. This option results in the lowest cost of purchased fertilizer. Apply around $50 \mathrm{lb}$ N/A in the early spring to maximize much-needed forage. Do not apply P or K recognizing that $\mathrm{N}$ will be the limiting nutrient in this low-cost option.

As described above, a consolidated soil and a tissue sample from each field should be submitted to the Lab for determining the lime requirement and phosphorus fertilization needs. Lime and phosphorus recommendations will be made as per the interpretation provided above.

Medium-Nitrogen Option. Apply $100 \mathrm{lb}$ N/A in the early spring to provide much-needed forage. At this level of $\mathrm{N}$ fertilization, $\mathrm{P}$ and $\mathrm{K}$ may be limiting if your soil tested low in these nutrients. Apply $25 \mathrm{lb} \mathrm{P}_{2} \mathrm{O}_{5} / \mathrm{A}$ if your soil tested very low or low in $\mathrm{P}$ and none if it tested medium or high. Apply $50 \mathrm{lb} \mathrm{K}_{2} \mathrm{O} / \mathrm{A}$ if your soil tested very low or low in $\mathrm{K}$ and none if it tested medium or high. Retest your soil every second or third year to verify $\mathrm{P}$ and $\mathrm{K}$ levels.

High-Nitrogen Option. Apply $160 \mathrm{lb}$ N/A and the soil-test recommended rates of $\mathrm{P}_{2} \mathrm{O}_{5}$ and $\mathrm{K}_{2} \mathrm{O}$ for each of your pastures. Split the $\mathrm{N}$ into two applications of $80 \mathrm{lb}$ N/A each, applying in early spring and early summer. The fertilization rates suggested in this option are high enough to allow bahiagrass pasture to achieve well above 
average production. Management and environmental factors will determine how much of the potential production is achieved and how much of the forage is utilized. A single cutting of hay can be made without need for additional fertilization.

Fertilization of Pastures with Biosolids or Manure. Apply no more than $160 \mathrm{lb}$ of total N/A per application and no more than $320 \mathrm{lb}$ of total N/A per year. (Note: In areas designated as phosphorus sensitive, the rate of application will be determined by other criteria).

\section{Special Note if Applying Manure or Biosolids}

A different set of economic factors are usually considered when waste materials rather than purchased fertilizer are supplying the nutrients. Additionally, it is often impractical to follow the application timings discussed in this footnote when using waste materials from other operations.

\section{Bahiagrass Cut Sometimes for Hay}

For a Single Cut Per Year from Pastures. If you used the Low-N option of pasture fertilization, apply $80 \mathrm{lb}$ N/A and the soil-test recommended amount of $\mathrm{P}_{2} \mathrm{O}_{5}$ and $\mathrm{K}_{2} \mathrm{O}$ no later than six weeks before the growing season ends. If you used the Medium-N option of pasture fertilization, apply $80 \mathrm{lb} \mathrm{N}$ and $40 \mathrm{lb} \mathrm{K}_{2} \mathrm{O} / \mathrm{A}$ no later than six weeks before the growing season ends. If you used the High-N option of pasture fertilization, you do not need any additional fertilization to make one cut of hay.

\section{Bahiagrass Grown Only for Hay}

For Multiple Cuts of Hay. Apply $80 \mathrm{lb}$ N/A and the soil-test recommended rates of $\mathrm{P}_{2} \mathrm{O}_{5}$ and $\mathrm{K}_{2} \mathrm{O}$ in early spring. Apply an additional $80 \mathrm{lb} \mathrm{N}$ and $40 \mathrm{lb} \mathrm{K}_{2} \mathrm{O} / \mathrm{A}$ after each cutting, except the last in the fall. Include $20 \mathrm{lb}$ of $\mathrm{P}_{2} \mathrm{O}_{5} / \mathrm{A}$ in the supplemental fertilizer if the soil tested low or medium in $\mathrm{P}$.

\section{Bahiagrass for Seed Production}

Apply 60 to $80 \mathrm{lb}$ N/A and the soil-test recommended $\mathrm{P}$ and $\mathrm{K}$ in February or March. Graze until May, June, or July, depending on variety. Remove cattle before seed heads start to emerge and apply an additional 60 to $80 \mathrm{lb}$ N/A.

If the bahiagrass is not grazed, do not apply fertilizer in February or March since this may stimulate excessive top growth. Mowing from February to April may be needed to remove excessive top growth. Apply the soil test recommended $\mathrm{P}$ and $\mathrm{K}$ and 60 to $80 \mathrm{lb}$ N/A before seed heads first appear. Fertilize Pensacola in March/April and Argentine and Paraguay in May/June.

\section{HAY OR SILAGE (PERENNIAL GRASS)}

\section{For Multiple Cuts}

Apply $80 \mathrm{lb} \mathrm{N} / \mathrm{A}$ and all of the recommended $\mathrm{P}_{2} \mathrm{O}_{5}$ and $\mathrm{K}_{2} \mathrm{O}$ in early spring. Apply an additional $80 \mathrm{lb} \mathrm{N}$ and $40 \mathrm{lb} \mathrm{K} 2 \mathrm{O} / \mathrm{A}$ after each cutting, except the last in the fall. Include $20 \mathrm{lb}$ of $\mathrm{P}_{2} \mathrm{O}_{5} / \mathrm{A}$ in the supplemental fertilizer if the soil tested low or medium in $P$.

For a Single, Late Season Cut from Pastures.

If you have not applied $\mathrm{N}$ in the past two months, apply $80 \mathrm{lb} \mathrm{N} / \mathrm{A}$ and the soil-test recommended amount of $\mathrm{P}_{2} \mathrm{O}_{5}$ and $\mathrm{K}_{2} \mathrm{O}$. If you have applied $\mathrm{N}$ in the past two months, do not apply any $\mathrm{N}$ now, but do apply the soil-test recommended amount of $\mathrm{P}_{2} \mathrm{O}_{5}$ and $\mathrm{K}_{2} \mathrm{O}$. Any application of fertilizer should be made no later than six weeks before the growing season ends.

\section{Special Note if Applying Manure or Biosolids}

A different set of economic factors are usually considered when waste materials rather than purchased fertilizer are supplying the nutrients. Additionally, it is often impractical to follow the application timings discussed in this footnote when using waste materials from other operations.

133. FERTILIZATION MANAGEMENT NOTES FOR LIMPOGRASS (Hemarthria) 
Establishment of New Plantings

For establishment of new plantings, apply $100 \mathrm{lb}$ N/A and split as follows: apply $30 \mathrm{lb}$ N/A, all of the $\mathrm{P}_{2} \mathrm{O}_{5}$, and $50 \%$ of the $\mathrm{K}_{2} \mathrm{O}$ as soon as plants have emerged. Apply the remaining $\mathrm{K}_{2} \mathrm{O}$ and 70 lb N/A 30 to 50 days later.

\section{Maintenance Fertilization of Established}

Pastures

For grazed, established stands, apply $60 \mathrm{lb}$ N/A and all of the $\mathrm{P}_{2} \mathrm{O}_{5}$ and $\mathrm{K}_{2} \mathrm{O}$ in late winter or early spring. Apply an additional $60 \mathrm{lb} \mathrm{N}$ in late summer or early fall. For a minimum fertilization alternative, ignore the $\mathrm{P}$ and $\mathrm{K}$ recommendation and apply only $60 \mathrm{lb} \mathrm{N}$ per year.

\section{Making Hay, Silage, or Green Chop}

Apply $80 \mathrm{lb}$ N/A and all of the recommended $\mathrm{P}_{2} \mathrm{O}_{5}$ and $\mathrm{K}_{2} \mathrm{O}$ in late winter or early spring. Apply an additional $80 \mathrm{lb} \mathrm{N}$ and $40 \mathrm{lb} \mathrm{K}_{2} \mathrm{O} / \mathrm{A}$ after each cutting, except the last in the fall. Include $20 \mathrm{lb}$ of $\mathrm{P}_{2} \mathrm{O}_{5}$ in the supplemental fertilizer if the soil tested low or medium in P.

Special Note if Applying Manure or Biosolids

A different set of economic factors are usually considered when waste materials rather than purchased fertilizer are supplying the nutrients. Additionally, it is often impractical to follow the application timings discussed above when using waste materials from other operations. 
$\sqrt{1}+\frac{1}{4}$

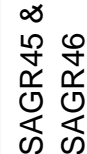

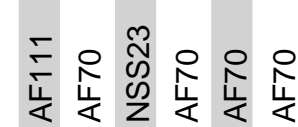

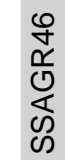

$\begin{array}{lllll}0 & 0 & 0 \\ 0 & 0 & 0 \\ 0 & 0 & 0 \\ 0 & 0 & 0 & 0 \\ 0 & 0 & 0 & 0 \\ 0 & 0 & 0 & 0 \\ 0 & 0 & 0 & 0\end{array}$

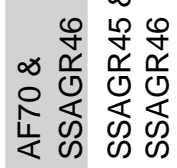

들

$\stackrel{+}{\mathbb{}}$

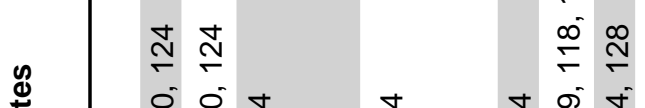

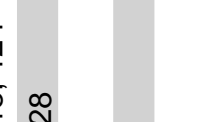

는

กิ

吉

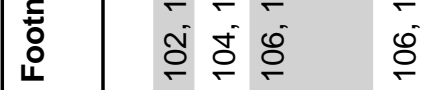

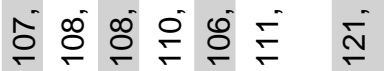

क काष

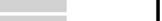

兽

$\mid \begin{array}{lllll}I & 0 & 0 & 0 & 0 \\ \bar{I} & 0 & 0 & 0 & 0\end{array}$

월ㄹㄹ

우웅으

क्ष

응

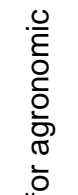

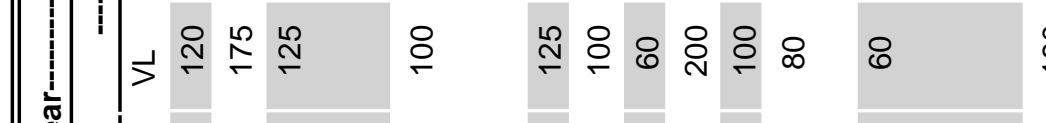

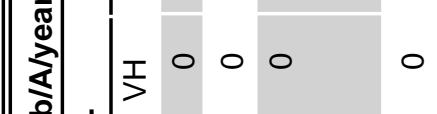

은

$\stackrel{+}{\stackrel{4}{N}}$ a 어 응 웅응

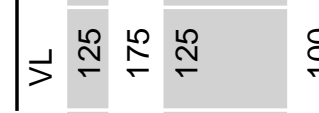

용ㅇㅇㅇㅛ 용

กิ

เก

$\stackrel{\text { సิ }}{\stackrel{1}{\leftarrow}}$

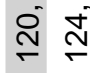

$\stackrel{\text { ล }}{\sim}$

$\stackrel{\stackrel{ \pm}{\leftarrow}}{\stackrel{N}{\leftarrow}}$

$\circ 0$

00

$\circ 0$

00

옹ㅇ 우

요 $\infty$

요

\section{0}

更

요 음

$\stackrel{\llcorner}{\simeq}$ ㅇ

0000

$\circ \circ$

00

$\infty 0$ 우 우

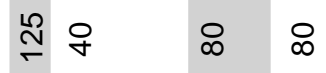

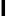

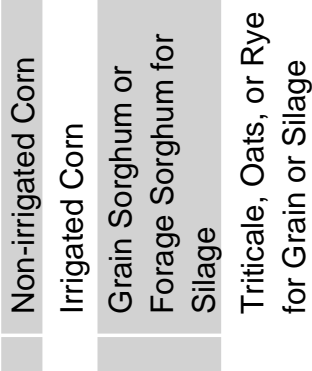

$8 \frac{0}{2}$

के के

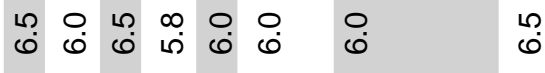

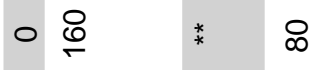

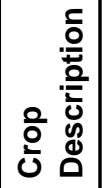

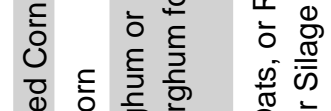

응 융

$\sim \infty \sim \infty$

๓윢ํำ

ล

ก

$\stackrel{\sim}{N}$ 


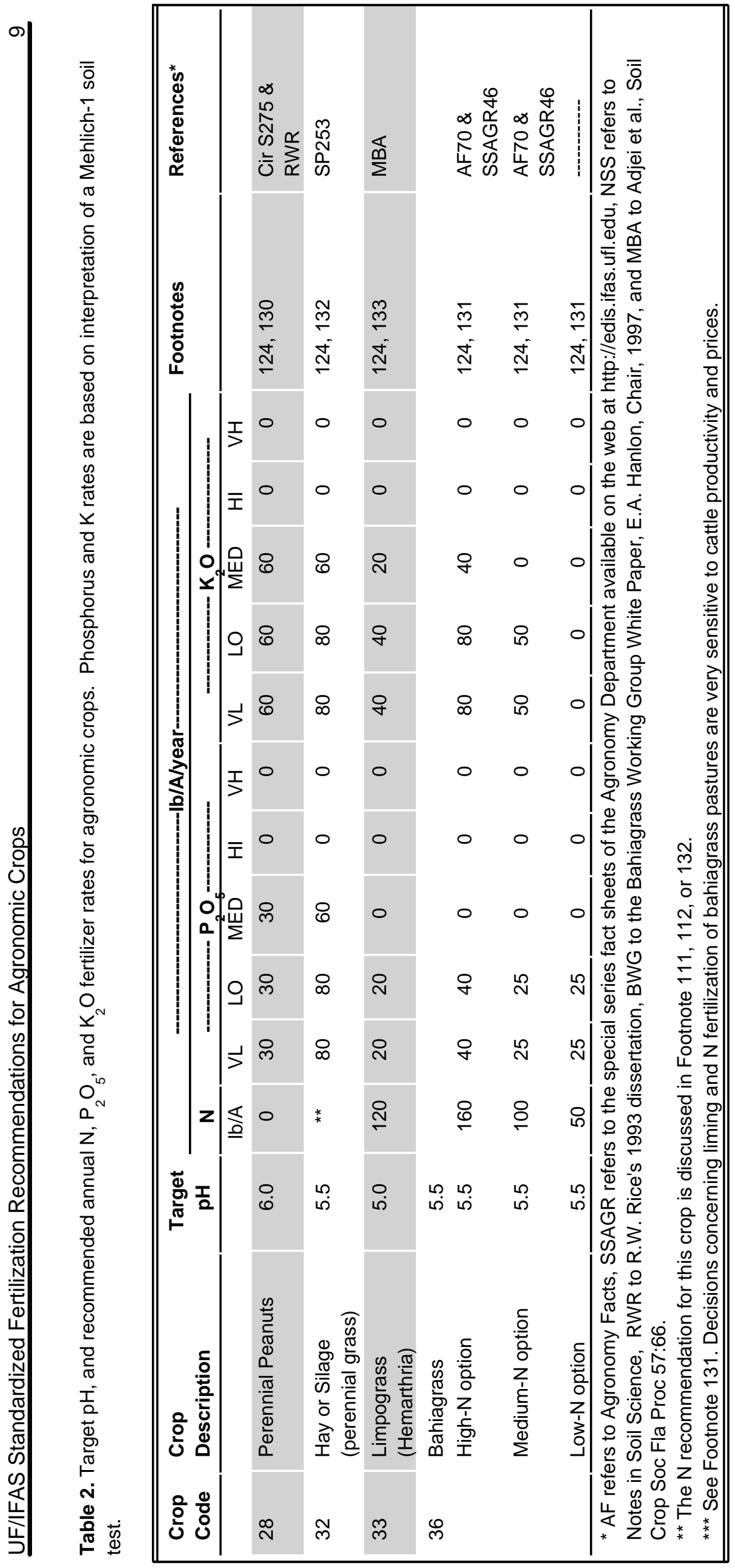

